\title{
"The true revolutionary is guided by a great feeling of love": papers in honor of Ananth Aiyer
}

\author{
Jeff Maskovsky ${ }^{1}$
}

Published online: 13 February 2016

(C) Springer Science+Business Media Dordrecht 2016

This special forum of Dialectical Anthropology explores the intellectual legacy of Ananth Aiyer, whose career as a radical scholar was cut short by his unexpected death in Spring 2015. Ananth made pioneering contributions to Marxist anthropology in his published work, as a relentless organizer of conference sessions and events, and as an editor of Dialectical Anthropology. This forum is comprised of personal testimonials and essays by several of his closest collaborators and friends: David Nugent, Winnie Lem, Anthony Marcus, Kathy Powell, and Gavin Smith. They first presented these pieces at a special event sponsored by the Society for the Anthropology of North America at the annual meetings of the American Anthropology Association, in Denver, Colorado, on November 20, 2015. I am very grateful to David, Winnie, Anthony, Kathy, and Gavin for sharing their essays with us here again, in print, and to Dialectical Anthropology, for publishing them. In addition to highlighting Ananth's many scholarly contributions, it is my hope that this forum will also remind readers-or give them a sense for the first time-of what intellectual life was like inside the orbit of one of the most charismatic, passionate, and politically committed Marxist scholars of his generation.

Ananth began his doctoral studies in anthropology at Temple University, in Philadelphia, in 1989. After conducting fieldwork among small miners in rural Nicaragua, he received his Ph.D. in 2004. In 2000, he joined the faculty of the University of Michigan, Flint. There, Ananth became Director of the International and Global Studies Program, in 2009. In 2012, he became the Chair of the Department of Sociology, Anthropology, and Criminal Justice, while in Flint, he worked with African American residents to publish an oral history of local civil

Jeff Maskovsky

jmaskovsky@gc.cuny.edu

1 The CUNY Graduate Center, Rm. 6405, 365 Fifth Avenue, New York, NY 10016-4309, USA 
rights activism. He also conducted new fieldwork in Kerala, India, from 2005 to 2015. Not in the least reticent about his Marxist commitments, Ananth was outspoken about the importance of connecting scholarship, teaching, and political action.

As many readers of Dialectical Anthropology are no doubt aware, Ananth was a larger-than-life figure in Marxist anthropological circles. He was an important leader in the effort to sustain the influence of Marxist anthropology during a period in which it had fallen out of academic fashion. I think it is safe to say that the lack of continuous serious engagement with Marxism in our discipline-at-large, and in academia in general, infuriated Ananth, so he devoted much of his career to the project of advancing Marxist scholarship whenever and wherever he could. He did this in many ways. He published articles. He co-edited Dialectical Anthropology. He went to conference after conference, organized panel after panel. And he worked hard with his students, many of whom went on to have stellar academic careers of their own.

The testimonials and essays that follow highlight both the ways that Ananth grounded Marxist theory in historical and ethnographic inquiry and the unique radical disposition that Ananth brought to his work. Winnie Lem, David Nugent, and Kathy Powell direct attention to not only Ananth's numerous contributions to the study of Central America, the USA, and India. They also emphasize at the level of theory the deep and unwavering critique of capitalism that informed his scholarly work, his insistence on a contingent, place-based understanding of class and of political economy, and the emphasis on contradiction, disorder, and conflict in actually existing capitalism. And they note as well the detailed attention to capitalism's internal heterogeneity that is on display in Ananth's articles, especially those on Nicaragua and India. Gavin Smith and Anthony Marcus give us a wonderful sense of the exuberance that Ananth brought to his intellectual work: of his Hurculian efforts to discover new Marxist work, especially from scholars outside of the Western academic mainstream, and of his insistence on the continued significance of scholarship that, fashionable or not, helps us to understand uneven and combined development, a Trotskyan formulation that Ananth found to be particularly useful. All of the essays give us glimpses of Ananth's sense of humor, of his charisma and charm, and of the outrage that he felt at capitalism's human costs, and at the scholars who refused to confront it head on.

In addition to his formal academic accomplishments, Ananth's influence was keenly felt outside of the formal spaces that the academy has established, as the essays also attest. Indeed, Ananth did some of his best intellectual work in conversations at bars, in the hallways of conference hotels, in hotel rooms long after the panels had ended, in the kitchen and around the dinner table, on the telephone, and on Skype. The kind of work that he did in these places is sometimes considered to be the ephemera of academic life. But I would hate for it to be considered as such in Ananth's case. This is a kind of work that we all do. But I think that Ananth did it particularly well. And that one of the many ways that we will powerfully feel his absence-indeed that I and many others have already felt his absence since his death-is that he is no longer a presence in those informal, unofficial places where good ideas often emerge, where academic networks become humanized, where 
people feel safe to play around with new ideas, and where they also feel safe to say what really matters and why.

Ananth nurtured and sustained the academic and personal lives of many people. He helped our academic community to flourish. I am very glad to have had him as a friend and comrade. And I hope that, in addition to the accounts of his intellectual contributions from the contributors to this forum, we will also remember the boundless energy he brought to the task of nurturing the rest of us and building our intellectual community. Ernesto "Che" Guavera famously said,

At the risk of seeming ridiculous, let me say that the true revolutionary is guided by a great feeling of love. It is impossible to think of a genuine revolutionary lacking this quality.

Ananth was certainly guided by a great feeling of love for his intellectual and political comrades. It is in this spirit that I invite you, the readers of Dialectical Anthropology, to join in the celebration of Ananth's work and life by reading these wonderful personal testimonials and essays. 